\title{
Language-ing the Earth: Experiential Renewal for a Relationally Sensitive Environmentalism
}

\author{
Patrick Howard, Cape Breton University, Canada
}

Email: patrick_howard@cbu.ca

\section{Abstract}

This paper investigates human relationship with the larger living landscape that is grounded in experiential renewal. Phenomenology is antithesis to the process of abstraction and objectification through which the world as we experience it is diminished by conceptualization and categorization. Recent studies to understand the natural world as a hermeneutic text offers important reflections on the human mediation of the meaning of the more-than-human-world and assists in understanding the implications of our encounters with the world. Phenomenology, however, is unique in its capacity to bring to expression, rather than silencing, our relationship with the natural world and our human inherency in it. This paper explores phenomenologically sensate reciprocity as it is encountered in lived experience. Through deepening our attunement for our embodied integration in a living world we may relearn and restore a capacity to dwell more thoughtfully with newfound sensitivity, respect, and restraint in the ecosystems on which we wholly depend.

Keywords: living landscape, experiential renewal, more-than-human, embodiment

\section{Introduction}

It is a drive through the mountains. My thoughts are taken up with the schedule of the day. Time seems to move slowly in contrast to the asphalt disappearing under the tires. On both sides of the car the landscape slides by; a blur of trees, road signs, and an occasional dwelling.

In a glance out of the side window something intrudes. In the instance of the glance I don't see the clear-cut on the mountainside as much as I register a rupture, a disturbance that penetrates. The rent in the forest is strangely unnatural. It is a blight, a discordance, and in the moment of the glance, somehow, the mountain seems to express this. It calls to me and stays with me. What kind of call is this? Is it a call that demands a response? In the same moment I sense an amalgam of emotions, the gaping hole in the forest implies brown earth compacted by heavy machinery, rutted and torn amid stripped stumps. It arouses guilt, shame, and anger in an instant. I vow to cancel the subscription to the advertising flyers that appear weekly on my doorstep. I feel responsible. But where is the source of this compelling sense of responsibility to be found? As I drive on, I become skeptical. I did not raze the forest. Nevertheless, how is it I feel this ethical 
demand when others seemingly do not? Forestry scientists, loggers, pulp and paper people, and politicians look on the same clear cut and may see economic benefit, board feet of timber harvested, jobs created, stumpage fees collected. Silviculture technicians may see the opportunity to replant to effectively manage this tract of land to maximize growth and future yield. How can this be so?

The forest, and the trees therein, have different meanings for those that perceive them. In this sense then the forest is both interpretive and narrative. We may even say the forest can be considered a text to be read and experienced. How I interpret the forest text depends on the narrative I project onto it. Each individual represents a different interpretive view. The forest may be home to those who seek refuge and a simple existence tied closely to forest rhythms. The forest may be regarded as a living entity, a networked, intelligent, biophysical life-force. The planet depends on the forests for continued health and vitality, especially in an age of increasing greenhouse gas emissions and the forests' capacity to sequester carbon. Forests play a significant role in the global carbon cycle having absorbed approximately one third of recent anthropogenic emissions of carbon dioxide (CO2) to the atmosphere. (UNECE, 2021) To the hiker, camper, or wilderness traveler the forest may have meaning associated with freedom, adventure, or thrill seeking. Forests, as a resource, represent the complex needs of large multinational lumber companies, paper mills, and small sustainable saw-milling operations on which thousands of people and whole communities depend for their livelihood. First Nations people may read the forest as sacred text - a place of animated spirit and venerated sites important to cultural practice and individual identity.

Each interpretation requires a response to key questions: Whose interests does the forest serve? Who benefits and is empowered in any particular forest narrative? Quite often the narratives and the values the narratives represent conflict with one another. Hikers, loggers, hunters, First Nations, large corporations, communities, environmentalists, and outdoor educators contribute to the conflict of interpretations that represent, for the most part, an anthropocentric view of the forest. An essentially hermeneutic and critical task is called for - one that invokes meaning, interpretations, narratives, values, ethics, politics, conflict, and mediation through dialogue.

But the hermeneutic undertaking also begs elemental phenomenological questions. Where is the voice of the forest in the dialogical arbitration of conflicting perspectives? Does the forest have a voice or language with which to speak? If so, is it possible to hear it, to experience it, to understand it, and ultimately to be responsive to it? In what way may the forest be considered 'Other' and exert an ethical demand upon us? What is it like to experience such an ethical imperative? 


\section{An Earth That Stirs}

These questions may be taken up by Levinas's description of the ethical relation. Selfinterest, cynicism, or indifference notwithstanding, if human beings fail to consider the ethical command of an-other - either human or non-human - if they are oblivious to its force, does this excuse them from the call to response-ible action? And again, what $i$ s this call? Is a voice even required? What is needed to in vocare, to raise a voice and elicit, to draw and bring forth the imperative?

I am scheduled for the first meeting with my doctoral supervisor at his home. On a beautiful late-August afternoon, I am graciously received, and we sit under an umbrella in the garden. I am nervous. My head is full of the things I have been reading. My profound wish is to make a good first impression, be lucid. coherent, and knowledgeable as I attempt to share with him some ideas I have for a dissertation topic. After some pleasant small talk, my supervisor leaves to bring cool drinks.

It is warm and pleasant; the umbrella above my head flaps gently in a soft breeze. And then I hear it. Unmistakable. Pushing through the anxiety comes the sound of an apple loosening itself from the branch of the tree behind me - a slight stirring, a rustle of leaves, and a soft thud that I believe now I felt, as well as heard.

The apple falls. And in that act, there lurks an intentionality, an intelligence, if you will, that reverberates through the ground, and up through my body. It came to me as a rustling sentience, born on a soft breeze that flapped in the awning and played with the shadows in the corners of the garden. For a moment I am focused; my senses are taken up, open to a world alive, awake, and aware. In that instant, I am involved. There are times when something of the biotic world, or as David Abram (1996) calls it, the more-than-human-world intrudes on our consciousness, breaks through the protective membrane, the filter of perception, and speaks to us. What happens then? Today we live almost exclusively in relation to other humans and see ourselves reflected largely in a human-built world. How are we able to move through this world and be unaware of a living landscape, yet at other times be acutely drawn to an unsuspecting encounter with the natural world? What are we to make of such experiences?

And just what does it mean to be involved? The word involve comes from the root word in Latin involvere, meaning to envelop, surround, literally "to roll in." As the apple rolls to rest in the grass or a clear-cut forest emerges suddenly in my field of view, it seems I am taken up on several different levels at the same time. There is an uncanny immersion, an interperformance. I am bound up in it. Linguistically, we have seemed to have lost this sense. In English, we observe. We see or watch. Look at. Listen to. But the French language seems to still have a sense of interperformance; to watch a parade is participer une parade, to partake, to share in the moment. This engagement is especially present when it is the non-human world that's being 
engaged, for there is no glass wall, no two-way mirror between the other-than-human-world and us.

I take my children to a renowned zoo. The main attraction is called Encountering Wild Africa. We are separated from the animals by plexiglass and concrete moats. "Why won't the lions come out of the cave Daddy?" We wait and watch, anticipating the performance. We are mere spectators. 'Please Do Not Tap on the Glass' read the signs on every pet shop aquarium. Spectators want a show. And yet even in a zoo the other-than-human is not devoid of its power to stir. Cynthia Thomashow (2002) describes walking into the reptile house at the Brookfield Zoo in Chicago and shuddering when he came upon a group of six teenagers transfixed on a python molting its skin. The teens cheer the python while simultaneously shivering and expressing repulsion at its behavior. Thomashow writes, "They seemed unaware of their collected movements, which mimic the undulations of the snake. I watched a group dance of sinuous and raw sensuality" (p. 258). Thomashow spoke to the teens later and one of them mentioned a likeness between the python shedding behavior and changes in human personality. Each young person told a story of shedding undesired traits and commented on the difficult process of change and vulnerability. Moreover, one teen said, "I felt such an intense shiver of knowing when I looked into the eyes of the snake it made my skin crawl, as if I knew everything at once, like the spirit of the world lay behind those yellow eyes and he was beckoning me out" (p. 259).

Phenomenology provides a way we can activate and reactivate the complex articulations and relations of things, restoring through descriptions, a bodily, imaginative, and participatory engagement with the other than human. Phenomenology allows a turn to the articulateness of things - to their grounded-ness, just as it was for those young people, phenomenology provides a way to return to the conditions of human embeddedness in the world. Naturalist Roderick HaigBrown writes, "It may seem strange to write of observation as participation, but no man (sic) is solely an observer of the natural world... We are basically all hunters, or gatherers, gleaners or predators, we all feel the weather in our face at times, and the things that stir and change about us stir within us also. (qtd. in Grady, 1997, p. ii) There is something primordial in Haig-Brown's words that doesn't fit with what I know of myself. It is too dramatic. Too primal. Yet, I understand my very being is sensate. My eyes, ears, skin, nostrils, and tongue are receptors. They receive. We are fine-tuned for relationship. The rusting flap, the flitting shadow, the minute shifts in light and sound find their way in, and down, to forgotten places.

The poet Rilke was moved to write about a panther he observed at the zoo. The big cat pads interminably behind iron bars. Rilke watches and watches and then slowly he is drawn in, becomes - immersed - involved. It is when the poet glimpses the otherness of the panther, when the panther is no longer an object to be looked at that the experience becomes relational. Something stirs within the panther and likewise, stirs within the poet. Rilke writes, "Only at times, the curtain of his pupils/lifts, quietly - An image enters in, rushes down through the tensed and arrested muscles, /Plunges into the heart and is gone" (Fisher, 2015, p.213). One wonders what Rilke saw when the curtain lifted? In whom did the curtain exist? Poet or panther? 
What are we to make of this stirring? A stirring is palpable, it is felt, a sensation. A memory, a sense, the inarticulate, the pathic is lifted out and brought close to the surface. When a person awakens from sleep, not yet fully conscious but on the threshold, we say, "Ssshhh... be quiet she is stirring." There is tension if we do not wish the person to awaken, or great anticipation if we do. Nevertheless, there is the sense that something is about to come to light, to be revealed.

My friend Dan has a profoundly autistic boy, whose name is Daniel. The boy was painfully uncommunicative as only autistic children can be. Daniel's occasional monosyllabic utterances were always prompted and usually mimetic. When the small boy was about six years old our families spent the day together on a beach. Dan walked with Daniel across rocky outcroppings to pools revealed by the retreating tide. I remember watching them from my place on the beach. I also remember thinking they were perhaps too close to the powerful riptide and waves that crashed in sprays of white spume just a few meters from them. The father and son stayed there for almost an hour - their silhouettes appearing and winking out against the brilliance of the ocean. When they finally returned to the beach, Dan rushed to his wife, breathless, and in telling her told us all, "It was incredible. Daniel didn't want to leave. He wanted to get closer and closer to where the waves were breaking. I told him it was dangerous. I said, 'No, not too close.' But I didn't want to scare him, you know. But he did the most amazing thing. He stood out there, closed his eyes, lifted his arms and said over and over. 'I be freeeee! I be freeee!! He's never done that before, never said anything like that before." "Where did that come from?" Dan asked his wife. Turning to us I could see tears welling in his eyes.

Where indeed?

We have no way of knowing what stirred Daniel to respond to the wind and the waves as he did, or what his response really meant. Who would not be moved by the drama and power of the surge leaping high over jutting rocks and running in lacy cascades of foam over the landward side of massive boulders? Yet this autistic boy locked behind a wall those who love him cannot breach is moved to break through, momentarily, and hurl his tiny voice out into the sea. He is called, and answers in response. The ocean sparkles with energy and activity. It seemingly responds to emotion and calls forth feelings in return. In Gendlin's (1992) discussion of Heidegger's befindlichkeit - the mood-wise situatedness of being - Gendlin describes the implicitness of feeling, the sense of inherency in feeling "that is never quite equal to any cognitive units" (p.52). Gendlin writes of feeling being a "lifting out" and this lifting out leads to articulation, "the feeling knows how to speak and demands just the right words. The feeling, more exactly, is sufficient to bring the words to the person's speech" (Gendlin, 1992, p. 52). Daniel responded - a felt response that had the power to guide speech.

Daniel, previously locked within a bounded self for a moment, opened himself, threw his hands in the air, and felt the rush of wind on his skin as the pounding, swirling amalgam of 
sound and sensation thrilled his small body. It was as if a boundary had been breached. Perhaps it was as Merleau-Ponty described it, that at the heart of human experience, no matter how abstract or seemingly cerebral the experience may seem, is the sentient, breathing body. The body is a plane of exchange. It draws its life from air, sunshine and water; its boundaries are porous. As it draws from the world, so it contributes. The body allows my entering into a relation with all things. The wind buffets and small grains of sand sting my face. Far below my awareness the conversation is ongoing. Merleau-Ponty, as David Abram (1992) reminds us, describes this level of perception as a reciprocity, an ongoing exchange between my body and its environment as a continuous attuning of my body to the outside world it inhabits.

A small boy stands on the strand, on a beach which is the border, a boundary between land and sea. It is the point of contact - con-tact as a touching together. The ocean chafes and pummels, the land yields ever so slowly. We are touched. The wind, the spray, the rattling, foamy retreat over rounded cobbles are capable of touching us on the outside, the boundary which we present to the world. But they touch the inside; the boundary that protects also binds. The world is drawn within us, so to speak; we are emotionally, imaginatively taken up and engaged. And yet there is danger here and vulnerability. We are drawn to the phenomenon, to the beauty and power, yet the risk inherent in this contact is undeniable. Daniel's father restrains the boy, "Not too close." We do not truly belong beyond the beach, beyond the boundary. There can be no "one with nature" here. Can there ever truly be? We live in the difference; it seems we are most human when we embrace and negotiate our separateness. The little boy speaks for he is called. There is a dialogue. In this dialogue is the power of language. There is energy, vitality and a moment of truth. Speech and thought, said Merleau-Ponty, are "the perceptible world's explosion within us." (in Fisher, 2002, p.127) We give voice to the world in which we are immersed speaking from inside the world. Borders and boundaries, inside and outside, shift, and ebb and flow.

\section{An Earth That Speaks}

Alphonso Lingis writes,

To live is to echo the vibrancy of things. To be for material things is to resonate. There is sound in things like there is warmth and cold in things, and things resonate like they irradiate their warmth and cold. The quail and albatross, the crows and the hummingbirds, the coyotes and the seals, the schooling fish and the great whales, the crocodiles infrasonically and the praying mantises ultrasonically continue and reverberate the creaking of the branches, the fluttering of leaves, the bubbling of creeks, the hissing of marsh gases, the whirring of winds, the shifting of rocks, the grinding of continental plates (2000, p. 108). 
These sounds are not inert, nor are they passive, or unintentional. As a boy I would 'caw' to the crows, and they would caw in response. I would mimic and then notice and re-produce subtle variations in pitch and tone. Our 'conversations' would continue until one of us bored of the game. Later in life, I would happen upon a crow funeral. One of their numbers had been struck by a motorcycle and lay dead on the sidewalk. The others lined the wires and tree branches issuing forth a cacophony of unmistakable lamentation and alarm. I stopped, transfixed, and saw these ubiquitous birds for the first time, as truly attentive, conscious beings, engaged in their world as we are engaged in ours. I felt their angst. I was unsettled. The crows' weaving, bobbing cries connected my senses in what I perceive. Or rather, what I perceived gathered my senses in a coherent way, and I experienced the phenomenon as a chiasma - a relationship. When a crow swoops from the wire, struts before me and cocks a shiny black eye my way, I am forced to consider that he is a sentient subject like myself, and that I too am an object for his gaze. Is it possible that this non-human entity, this Other may be as Levinas (1985) points out, an Other that calls to me, calls for a response that is the very source of all language and culture, and is therefore a "source of instruction?" (p. 46)

To see the crow laid low, torn and bleeding, its downy breast feathers lifting in the breeze while lamentations fill the air - this seems to be the nakedness, the flesh, the vulnerability of which Levinas writes, the lone crow that struts before me, the inky blackness of its eye enveloping me with each quick shutter. I cannot deny my feelings. The crow seems bold, confident in the face of death. Can this be the facing of the face of the other of which Levinas (2000) speaks, “...in this mortality - a summons and a demand that concern the I, that concern me, as if invisible death with the face of the other faces were my business, as if that death had to do with me?" (p. 175). Deihm (2003) points out that when Levinas was asked about the faces of animals he was unsure how to respond. He struggled and spoke of the faces of dogs, and saying of snakes, "I don't know if a snake has a face. I can't answer that question" (p. 172). Deihm speculates that the lack of a definitive response by Levinas may be indicative that non-human others have failed to impress themselves upon Levinas. Deihm (2003) writes, “...but it may be more fruitful to ask why he does not immediately reply in the negative. Why, that is, do such others give him pause?" (p. 172) There is a sense that there is something disquieting for Levinas about the notion of the death of any living being. Levinas struggles probably because he is aware of his own philosophical principles, for he cautions against reducing the face to $a$ face. Levinas (2000) writes,

You turn toward the Other as toward an object when you see a nose, eyes, forehead, a chin and you can describe them. The best way of encountering the other is not to even to notice the color of his eyes. When one observes the color of the eyes one is not in a social relationship with the Other. (p. 85)

Levinas cautions against reducing alterity to simple difference, "the other must be received independently of his qualities." Then it seems Levinas' notion of 'Other' would be more 
inclusive than exclusive. But no matter, for as I stood on the sidewalk that day I was spoken to in the suffering lamentation of the birds on the wire, spoken to by the naked vulnerability of the dead bird in the grass, spoken to, and momentarily caught up in a sense of belongingness to the struggle of beings striving to maintain a tenuous hold on life.

Lingis (2000) also points to a dialogue, to a participatory relation with the non-human world. He describes the sounds of the Earth as background noise which communicates in a reciprocal relationship,

For we too communicate what we communicate with the background noise. As we communicate the background noise. The communication takes place when the vibrancy of the land, the oceans, the skies is taken up, condensed, and unfurled in the hollows of one's body, then released, and when one hears its echo returning with the wind and the sea. (p. 108)

As we have seen, Merleau-Ponty in Phenomenology of Perception approaches human speech as a felt, bodily expression. He ties language firmly to its expressive nature, to gesture, movement and direct sensation as does Abram (1996) who writes,

...only by conceiving language as purely abstract phenomenon can we claim it as an exclusively human attribute. Only by overlooking the sensuous, evocative dimension of human discourse, and attending solely to the denotative and conventional aspect of verbal communication can we hold ourselves apart from, and outside of, the rest of animate nature (p. 79).

The physical, resonant, expressive dimension of language described by Abram plays out on my bus ride one afternoon. An elderly Asian woman takes her seat directly in front of me. After a couple of stops another elderly Asian woman boards. Recognizing her, the woman in front of me waves her hand excitedly and calls to attract the other woman's attention. Their faces, their bodies, their voices communicate to me what their words cannot, for I do not speak their language. Yet, in a sense I do. These is a tonal, melodic quality that accompanies the words of surprise and greeting. It is musical, pleasant. Voices conjoin, co-mingle, their hands touch, and they both briefly cover their mouths in a display of embarrassed excitement. Their actual words skim the surface for meaning in this encounter is written deep in the sensory life of their bodies. I too sense their excitement and cannot help but smile at their surprise to have found each other on this bus. The words I do not understand; yet, meaning is anchored in their gestures and bodily expressiveness.

This is a language shared by sentient, expressive, experiencing beings. Merleau-Ponty expands the ability to communicate and actively solicit the participation of our sense to all 'things.' It seems nothing presents itself as passive or inert to the sensing body. There is dynamism, animated-ness - every phenomenon has the power to touch us, to push inwards, to 
pierce the membrane of awareness and influence us in some way. Merleau-Ponty writes, "It is through my body that I understand other people, just as it is through my body that I perceive "things' (1962, p. 2016). Later in the same chapter he writes, "It is the body which points out, and which speaks... this disclosure of an imminent or incipient significance in a living body, extends. To the whole sensible world, and our gaze, prompted by the experience of our body will discover in other "objects the miracle of expression" (1962, p. 230). We may understand this to mean that at the level of the bodily, felt experience we live in an animate environment - on an earth that speaks.

\section{An Earth That Sees (and Hears)}

It is close to midnight on a cold clear October night. My wife and I speed down a deserted highway. We become aware of light on the horizon outlining the black silhouettes of tall spruce that gird the roadway. "The Northern Lights, "my wife exclaims. I bring the car to a rolling halt on the gravel shoulder. Turning the engine off we step out into the night. The lights of the aurora shift and move. Sometimes there are shafts of yellow tinged with green, then masses of evanescence that move from east to west and back again. Great streams of bluish white undulate like a tremendous curtain. Then slowly the curtain contracts, folds in on itself, concentrates. The lights seem to drain away to form one gigantic, ominous rosette of yellow and purple flame. I notice my heart beating. I feel threatened and undeniable fear. I turn to my wife who murmurs, 'Let's go. I'm scared.' I fumble for the car keys. We speed away in our little human satellite, and laugh, embarrassed now. Over the years we have told our story to friends around the dinner table or the campfire. No one has snickered dismissively-people just nod knowingly.

What are we to make of such experiences? What was there to fear? Using the laws of physics and astronomy, the aurora is a perfectly explainable natural phenomenon. Rationally, I know the explanation. Yet, I cannot deny my pounding heart. I felt thoroughly cowed by an undeniable experience of Merleau-Ponty's notion of perceptual reciprocity. To gaze upon the Northern Lights is to feel oneself exposed and visible to the aurora. Just as the animate world speaks so too it seems to see, to listen and hear. Van Manen (2003) describes a similar experience," Truly there must be something deeply meaningful in the universe around us. Gazing into the sky one may experience a strange sensation of being gazed at by something beyond oneself." (p. 14) While the experience does induce us to wonder and project outwards beyond the physical realm, the awe the aurora inspires is no less warranted when we consider other possibilities. There is the possibility that we are not mere spectators but participants in the aurora. Merleau-Ponty reminds me that I am able to touch things because my hand itself is a touchable thing. To touch the rough, sticky bark of a spruce tree is simultaneously to sense my own hand and fingertips - to feel myself touched by the tree. To see the aurora is, similarly, to experience myself as visible, to feel 
myself seen. I am reminded of a passage in Annie Dillard's (2000) book For the Time Being. Dillard refers to Pierre Teilhard de Chardin, the French paleontologist, priest and mystic. It reads, "By means of all created things, without exception, the divine assails us, penetrates us, and molds us. We imagined it as distant and inaccessible, whereas we, in fact, are steeped in the burning layers." (p. 171). These words somehow reverse the luminous shafts of the aurora, the tremulous curtains and colliding rosettes of swirling light and hurl them into my interior. My rational mind rebels at this. Writing such descriptions seems merely poetic and fanciful. But to say the lights of the aurora are thrown into my interior is not to leave my sanity behind, only my reason. To think about these things pushes language to the limit. When de Chardin says he is assailed, penetrated, molded I can go with him, but my reason cannot. This experience is in the realm of the poet and I come to know more deeply Rilke's (1995) words
Ah, not to be shut off
Not through the slightest partition
Shut out from the law of stars.
The inner-what is it?
If not intensified sky, hurled through with birds
And deep with the winds of homecoming. (p. 191)

Science cannot capture my experience of the aurora, for science abstracts the sensory experience declaring it subjective and therefore null. Strangely, too, projecting supernatural explanations nullifies my experience but in a different way. By assigning the experience to the supernatural, to only the divine, I remove the possibility that there is a commonality, an interdependence, that I, as perceiver and the thing I perceive, are as John Sallis (2018) says, part of the same elementals. Relying solely on either 'explanation' may be seen as a denial of our embeddedness, or participation in a cosmological whole.

The physicist Sigurd F. Olsen (1982) in his essay Northern Lights expresses the inability of reason, of a scientific, atomistic orientation to give voice in any meaningful way to the deeply felt presence of this astronomical phenomenon. Olsen describes beautifully the experience of skating on a seven-mile-long sheet of clear lake ice in northern Canada. Suddenly, he is aware of the aurora dancing in the heavens above him and simultaneously being reflected in the ice below him. At that moment, he says, he was a part of the aurora. As he lay on the ice to rest he thinks,

I knew what the astronomers and the physicists said, that they are caused by sunspots and areas of gaseous disturbances on the face of the sun that bombarded the earth's stratosphere with hydrogen protons and electrons of oxygen, nitrogen, and helium. Here they produced all the colours of the spectrum. It was all very plausible and scientific, but tonight that explanation left me cold. I was in no mood for practicality for I had just come skating down the skyways themselves and had seen the aurora from the inside. What did the scientists know of what I had done? How could they explain what had happened to me and the strange sensations I had known? (p. 97) 
Olsen struggles to make sense of what he had just experienced. He is energized, fully open to a living, breathing world. We can imagine him feeling his body supported by the solidity of the ice beneath him, his ears are attuned to the cracking, shifting forces, his eyes scan the spectacle of light, a clear frost stings his nostrils and sends his breath in a hoary spume. Yet the experience is not fragmented or compartmentalized. The experiencing body and its divergent senses meet up in the world, are open to the Other, open to relationship in which the world becomes present in all its depth. At that moment, Olsen the scientist rejects science. He looks elsewhere to meaning, confirmation assurance. He writes,

Much better the poem of Robert Service telling of the great beds of radium emanating shafts of light into the northern darkness... How infinitely more satisfying to understand and feel the great painting of Franz Johnson of a lone figure crossing muskeg with the northern lights blazing above it. I stood before that painting in the Toronto Art gallery on day and caught all the stark loneliness, all the beauty of the cold of that scene and for a moment forgot the busy city outside... I knew nothing then of protons or atoms and saw the northern lights as they should be seen. (1982, p. 97)

It seems the words "as they should be seen" is not through the eyes of an abstract, objectifying science, being measured and quantified by computer arrays and telescopes. In this instance, the biosphere is being experienced and lived from within an intelligent body that is fully open and aware, hearing and being heard, seeing and being seen- entirely a part of the world it experiences.

\section{An Earth Denied}

On a dark, lonely highway two people flee an overwhelming presence of a perceived, unsettling natural phenomenon - the aurora borealis. With urgency and trepidation, averted eyes and lowered voices, they seek the shelter of their car. Encapsulated in the human-built world, in the familiar glow of the dashboard electronics, they put distance between themselves and the Other. They leave it out there, push it away, force it back down. I am reminded of the biblical story of the people of Israel who pleaded with Moses to let God speak and God did.

And all the people saw the thunderings, the lightnings, and noise of the trumpet and mountain smoking; their fear was unimaginable. They asked Moses to beg God never to speak directly to them again. Let not God speak with us lest we die. And God pitying their self-consciousness, agreed. He agreed not to speak directly to the people anymore. And he directed Moses, "Go say to them. Get into your tents again." (Exodus 20:18 -19 in Bates, 1936/1993, p. 108) 
The lights in the northern sky in a vital, shifting dance of unique pattern and colour, in its own uncanny language of movement and energy communicates and disturbs. Like ripples and echoes, it shapes and draws our senses in unexpected directions. Loren Eiseley (1979) wrote of a similarly unsettling experience on a deserted mountain road. He initially describes such rare encounters as miracles he had sought all his life,

Just at this time, with my thoughts in a receptive mood, a summons came that made it necessary to make a long night drive over poor roads through a dense forest. As a subjective experience, which it turned out to be, I would call it a near approach to what I was seeking. There could be no doubt I was working toward the heart of the problem. The common man thinks a miracle can just be seen to be reported. Quite the contrary. One has to be, I was discovering, reasonably sophisticated to perceive the miraculous. It takes experience: otherwise, more miracles would be encountered. (pp. 157-58)

Eiseley, the man of science, the eminent anthropologist and naturalist, travels the mountain road and encounters a shadowy presence that he cannot identify, and which was "as much a shapeshifter as the wolf in the folktale." (p. 159). He continues,

It was not an animal; it was a gliding, leaping mythology. I felt the skin crawl on the back of my neck, for this was still the forest of the windigo and the floating heads commemorated so vividly in the masks of the Iroquois. I was lost, but I understood the forest. The blood that ran in me was not urban, I almost said not human. It has come from other times and a far place. (pp. 158-59)

Eiseley describes the unexpected, the surprise that comes with meeting the world with our animal senses. The discomfort, fear that arises when we find ourselves exposed in a living field with powers more expressive than the human world in which we most often live and move. Eiseley concludes, "Nature claims an otherness which incorporates man, but which man instinctively feels contains secrets denied to him" (1979, p. 225).

But how often is this denial of which Eiseley speaks, a denial of our own choosing? We deny, or are deaf to our incorporate-ness, of being united and part of a larger living body. Most of us live lives in which we see ourselves reflected solely in a world of our own making. It is a world of cars, busy streets, and streetlights that eclipse the night sky; it is a world of computers and smartphones, office buildings and shopping malls. The more- than-human world we do encounter is most often an artifice of the culture; neatly designed gardens with bedding plants from an industrial greenhouse, carefully mapped and maintained walking trails. Our food is neither grown nor raised by us. It appears in supermarkets wrapped in cellophane on Styrofoam trays. Heidegger wrote that this view of nature is one in which the nonhuman appears what is indifferently present (vorhanden). Natural entities are manifested in what Heidegger calls stock or standing reserve (das bestand) - simply resources for human consumption. 
I am aware this table on which I work retains an element of the biotic world. I see the grain and knotty whorls that bespeak the life from whence it sprang. Likewise, the electronic materials, alloys and petroleum products from which this laptop is made can all be traced back to the living world. However, the mass production, the refining and re-assemblage, the repetitiveness of a world of plastic and glass and synthetic fibres manufactured in endlessly repetitive forms have little to say to us once we have mastered them. They are far removed from the living world to which their lineage can be traced. They become objects. There is little dynamism that responds to our senses as eloquently as that of the living, organic world. We retreat to what is familiar; we find comfort and safety in what we know best. The little car speeds down the highway; the aurora fades in the distance. We flee, like the ancient Israelites to the security of our tents. The theologian Thomas Berry calls our modern condition a collective autism for the voices of the natural world. We suffer a growing diminishment in our intimacy with the Earth. Hutchison captures this diminishment is his narrative The Geese,

Every spring they head northward and south each autumn, the Canada goose, noblest of birds. Everywhere, but especially on the prairies, men look up and watch them, and never tire of the sight... Without compass, without knowledge of geography or power of reason, the geese move certainly, over thousands of miles to their habitation. No doubt here, no fear, no bewilderment. And men, doubtful always, afraid always, and in civilization completely bewildered, see the geese and they know that here is something, a freedom, a surety that they once had long ago but have mislaid in the glut of living.

The geese know their way, over trackless land, over men's cities and the empty tundra, while men for all their roads, maps, paraphernalia of travel, their cunning science, are lost. The geese fly boldly into the dark and wilderness, and it is friendly to them. Men flee from the dark and huddle in their cities, their tiny points of light behind flimsy walls. (1982, p. 107).

What have we lost or mislaid? That something seems to be perhaps our human inherence in a more-than-human world. We are inundated with evidence that the Earth and its myriad complex ecosystems are being thoughtlessly diminished and degraded. Rationally, I am aware of my reliance on the Earth for my very survival, yet my modern, reason-able mind feels, separate, independent somehow. We are told of the ecological crisis that has befallen us and yet most of us feel no real urgency. The English word crisis is derived from the Greek krinein which means to separate. It is the separateness that we feel, the experience of dissociation that may be largely connected to the growing ecological problems we currently face. The ancient Greeks used the word krisis in the sense of a deciding, a judgement, a sentence, the result of a trial. This may be a more fitting use of the word crisis as we question and seek to to renew our relationship with the Earth on whom we are completely dependent. 


\section{Reading the Earth}

A glance out a car window registers a tear in the fabric of a mountainside, an August breeze stirs the branches and an apple loosens and falls with a solid thud to rest in the grass. It is heard; it is felt. Heidegger sought to capture this sentience, this intentionality with the Greek word physis. Physis is that which unfolds and emerges of and from itself while continually returning back into itself. It is this self-emergence that Heidegger called the essential fullness of nature. The apple seed sprouts, the seedling emerges, grows, puts forth blossoms, sets fruit and extends itself into the open, yet "it simultaneously goes back into its roots, in that it fixes them in the closed and so it takes its stand" (Foltz, p. 13). Physis is the self-emerging that lingers and holds sway of its own accord. As we become aware of the unseen depths, we feel ourselves immersed in the living world around us. We become open, in degrees, to a sentient landscape in which we participate in sensate reciprocity with the myriad others. Only when we slip out of a world defined solely by the human and begin to trust the intelligence of our sensing bodies can we glimpse the generative depths and the things around us may awaken and come alive.

An experience shared with by a colleague seems to capture this attunement and awareness. She spent a week at a forest retreat centre and every afternoon before dinner passed time in quiet reflection. One particularly warm and brilliant afternoon she made her way from her cabin only to be struck by a "solar extravaganza" was how she described it. The sight of colourful butterflies flitting in the light as she walked the path. She wrote, "The sight of them made me stir and with the stirring I realized how they appeared as old friends." At the end of the day with the fading sunlight ebbing from her room she wrote,

As I lifted my eyes to the light streaming through the open windows, a solitary butterfly appeared in the room. Breathless and captivated with its beauty, I followed its elliptical path - de-lighted - through the illuminated air. As I closed the meditation text as the final syllable of the final line of the final prayer was uttered, the butterfly descended to rest, momentarily, on the text. I looked down on it amazed - its lace like wings of parchment not unlike this very text we preserved and recite through time. It lingered there sufficiently to suggest my thoughts and prayers were a wind it rode to land before me, to enjoy even momentarily the affection and rapt attention in which it was held. It lingered there is the serendipity of it all, in the beauty, in the pleasure of reading the world.

To read the world requires us to be aware, aware, alive to other forms of sentience that surrounds us in the present. It requires cultivating an ear, an eye, a feel for the language of the earth. Reading calls for a literacy that stems from an embodied, sensory knowing manifested through direct and participatory engagement with the myriad beings that surround us perceptually. When we come to our senses and slip under the human logic imposed on the world we may gain insight into how the Earth can guide us. I believe JH van den Berg (1961) the Dutch psychiatrist and phenomenologist instructs us in this attitude of attunement - in this sensibility for the language of 
the living world. He asks the question, when we walk with children and guide them in the ways of the world how many of us rely on abstraction and objectification? When asked by a child, 'why have the leaves turned red?' van den Berg says we must resist launching into the chemistry of chlorophyll or the physics of atmospheric conditions. These are inert ideas divorced from the child's experience. Van den Berg suggests another response, one that opens the child to a sensibility of wonder and attentiveness,

"Why are the leaves red, dad? Because it is beautiful, child. Don't you see how beautiful it is, all these autumn colours?

There is no truer answer. That is how the leaves are red. An answer that does not ... lead to an endless series of questions, to which each answer is a threshold. The child will hear later that a chemical reaction occurs in those leaves. It is bad enough, then; let us not make the world uninhabitable for the child too soon. (van den Berg, 1961, p.69)

To lead a child and so be led by a child is an experiential renewal, a rejuvenation of felt awareness for the world. To be present, aware of where you are in the moment is to be enlivened. It is trust, the tacit intelligence of the sensing body. Van den Berg also writes,

What makes a bulb sprout? The child asks, and we talk of seasons, substances, circulation, in short about past things, while only one answer is right: the plant wants to bloom. The sense of the sprouting lies in what everyone can see if he wants to see. Watch how the bulb sprouts and observe how it is ruled by one intention... Observe the present and show it to the child, show him the intentions of the present. (1961, p. 70)

An apple falls; it is heard; it is felt. It sends ripples through the air, through the Earth, and it speaks to us in a language we can learn to understand if we pay attention in the present.

\section{References}

Abram, D. (1996). The spell of the sensuous: Perception and language in a more-than-human world. Random House.

Bates, E.S. (1936/1993). The Bible: Designed to be read as living literature. Simon \& Schuster.

Deihm, C. (2003). Natural disasters. In C. Brown \& T. Toadvine (Eds.). Eco-phenomenology: Back to the Earth itself (pp. 171-185). SUNY, Press. 
Dillard, A. (2000). For the time being. Penguin.

Eiseley, L. (1979). The star thrower. Random House.

Fisher, L. (2015). The poet and phenomenologist: Rilke and the new proms: Bloomsbury.

Foltz, B. (1995). Inhabiting the earth: Heidegger, environmental ethics and the metaphysics of nature. Humanities Press.

Gendlin, E. (1992). Beflindlichkeit: Heidegger and the phenomenology of psychology. In K. Holler (Ed.), Heidegger and psychology (pp. 43-71). Brill Academic.

Grady, W. (Ed.). Bright stars, dark trees and clear water. David R. Godine Publishing.

Hutchison, B. (1982). The geese. In D. Ryan \& T. Rossiter (Eds.), Literary essays and short stories (pp.78-86). Jesperson Press.

Lingis, A. (2000). The murmur of the world. In W. Brogan \& J. Risser (Eds.), American continental philosophy (pp. 95 - 113). Indiana University Press.

Levinas, E. (1985). Ethics and infinity. Duquesne University.

Levinas, E. (2000). Entre nous. Columbia University Press.

Merleau-Ponty, M. (1962). Phenomenology of perception. Routledge.

Olsen, S. (1982). The northern lights. In D. Ryan \& T. Rossiter (Eds.), Literary essays and short stories (pp.47-58). Jesperson Press.

Rilke, M. (1995). Ah, not to be cut off. In S. Mitchell (Ed. and Trans.), The selected poetry and prose of Ranier Maria Rilke (p.191). Modern Library.

Sallis J. (2018). Elemental discourses. Indiana University Press.

Thomashow, C. (2002). Adolescents and ecological identity: Attending to wild nature. In P. Kahn \& A. Kellert (Eds.), Children and nature: Psychological, sociocultural and evolutionary investigations (pp.259 - 278). MIT Press.

United Nation Economic Commission for Europe. (2021). Carbon sinks and sequestration.www.unece.org/forests/carbon-sinks-and-sequestration 
Van den Berg, J. (1961). The changing nature of man. Dell. 